January 1992

\title{
Evaluation and Treatment of Demented Elderly
}

Barry Rovner, M.D.

Thomas Jefferson University

Follow this and additional works at: https://jdc.jefferson.edu/jeffjpsychiatry

Part of the Psychiatry Commons

Let us know how access to this document benefits you

\section{Recommended Citation}

Rovner, M.D., Barry (1992) "Evaluation and Treatment of Demented Elderly," Jefferson Journal of Psychiatry. Vol. 10 : Iss. 1 , Article 9.

DOI: https://doi.org/10.29046/JJP.010.1.008

Available at: https://jdc.jefferson.edu/jeffjpsychiatry/vol10/iss1/9

This Article is brought to you for free and open access by the Jefferson Digital Commons. The Jefferson Digital Commons is a service of Thomas Jefferson University's Center for Teaching and Learning (CTL). The Commons is a showcase for Jefferson books and journals, peer-reviewed scholarly publications, unique historical collections from the University archives, and teaching tools. The Jefferson Digital Commons allows researchers and interested readers anywhere in the world to learn about and keep up to date with Jefferson scholarship. This article has been accepted for inclusion in Jefferson Journal of Psychiatry by an authorized administrator of the Jefferson Digital Commons. For more information, please contact: JeffersonDigitalCommons@jefferson.edu. 


\title{
In Response
}

\section{Evaluation and Treatment of Demented Elderly}

\author{
Barry Rovner, M.D.
}

There are currently 27 million people over 65 in the United States and this number will double in the next 50 years. This will confront psychiatrists and other physicians with the care of many elderly patients with dementia. These patients will often require hospitalization when ill because their mental, physical, and social functioning tends to break down at once, overwhelming families and outpatient physicians. Once hospitalized, they require accurate diagnoses, multidisciplinary care, and planning for rehabilitation from the onset of the hospitalization. However, dementia is often undiagnosed and untreated in university hospitals as well as in primary care clinics and nursing homes. The consequences of this are limited prospects for clinical improvement and the likelihood of further decline.

Dr. Rosenberg's contribution to the Jefferson Journal of Psychiatry, "Psychiatric Consultation for the Demented Elderly" eloquently describes the dilemmas of caring for elderly demented patients in general hospital settings. It is notable that the psychiatric consultants' initial advice to prescribe a high-potency neuroleptic along with an anticholinergic agent is potentially problematic because of demented patients propensity to develop extrapyramidal side effects and delirium from these agents, respectively. Using a benzodiazipine is equally problematic because it may increase cognitive impairment and the risk of falls.

These complications contribute to the sense that general hospital wards are inappropriate places to care for demented patients. Instead, such patients may fare better on dedicated geriatric psychiatry/medical units where the milieu and approaches to care are designed to support impaired patients, compensate for their deficits, and stimulate their remaining capabilities to achieve their highest level of function.

Care on the unit should be carried out by a multidisciplinary team under the direction of a geriatric psychiatrist. The team should consist of geriatricians, and gerontologically-trained nurses, social workers, and occupational and recreational therapists. Dr. Rosenberg's case report illustrates the variety of dangers of an inappropriate placement. Physicians are angry, nurses are frustrated, the ward is

Dr. Rovner is Associate Professor of Psychiatry and Director of Geriatric Psychiatry at Thomas Jefferson University, Philadelphia, PA. 
disrupted, and the patient is at risk of further harm from the overuse or misuse of chemical and physical restraints.

Dr. Rosenberg makes the point when he writes, "The demented elderly require a special array of medical, nursing, and health care services which are distinctly different from what is provided on most general medicine or psychiatric wards." His conclusion that "most acute psychiatric hospitals are ill-suited for these patients" is accurate and poses the greatest challenge for the psychiatric care of this growing population of patients. 